\title{
Of cats and men: ancient DNA reveals how the cat conquered the Ancient World
}

Eva-Maria Geigl and Thierry Grange

Institut Jacques Monod, CNRS, UMR 7592, University Paris Diderot, Paris, Frances

\begin{abstract}
Neither genetics and genomics of modern cats nor archeology could so far reconstruct the domestication and dispersal process of the cat. It was only known that all domestic cats belong to the subspecies Felis silvestris lybica, that their genomes are close to the ones of wildcats and that they were translocated to Cyprus by the Neolithic farmers who colonized this island roughly 9,500 years ago. The results of our large-scale paleogenetic study of the mitochondrial DNA of archeological cat remains fill the existing gaps in that they allowed us to reconstruct the history of the dispersal of the cat starting in southwest Asia during the Neolithic and achieving a new quality in Egypt during the $1^{\text {st }}$ millennium BCE. Together with those from southwest Asia, these mitochondrial lineages from Egypt showed up in samples from the following centuries all over southwest Asia, North Africa, and Europe, testifying of the cat's conquest of the ancient world. The dispersal pattern that we reconstructed from our data tells us that cats accompanied seafarers throughout history on their trading and raiding routes.
\end{abstract}

Keywords Cat dispersal; domestication; ancient DNA; genetics

\section{Introduction}

Hundreds of millions of cats inhabit the world: They live as cherished companions and pets in urban households where they make families happy; as stray cats in cities; as village and barn cats in villages and farms, where they restrict rodent plagues; but also as feral cats in nature 
where they become a threat to wild birds and other vertebrates and, in some areas, an invasive species that exterminates the endemic fauna. Despite their popularity and widespread occurrence, however, little is known about their domestication.

\subsection{Genetics of present-day domestic cats based on mitochondrial and microsatellite DNA data}

Genetic studies showed that all domestic cats, including feral cats, are descendants from one of the five subspecies of the wildcat Felis silvestris lybica, the wildcat from north Africa (NA) and southwest Asia (SWA), while the other subspecies of Felis silvestris, such as the European wildcat Felis silvestris silvestris, did not make a major contribution to the gene pool of the domestic cat although hybridization between the two subspecies is clearly detectable (Driscoll et al. 2007; Oliviera et al. 2008; Mattucci et al. 2015) (Fig. 1). Apart from revealing monophyly for the domestic cat, mitochondrial DNA sequences and nuclear microsatellite DNA did not disclose the course of its domestication process since no population structure in the domestic cat population emerged.

\subsection{Archeozoology of cat domestication}

There are two other sources of information about this process. The first one is the archeological record, which is regrettably scarce. The cat has never been a subsistence species and is, therefore, rarely found as refuse in archeological sites. The wildcat being a solitary animal of elusive nature, it was probably never hunted and only occasionally killed for its fur in prehistoric times. This changed only during the Middle Ages in Europe when items made of the pelts and skins of domestic cats became popular among common people (Ewing 1981), as well as their flesh and other body parts (Von den Driesch 1992). There are, however, two archeological finds that stand out and hold a clue to the timing and location of the taming process of cats. The first one is a human burial in Cyprus dated to ca. 7,500 BCE in which a cat skeleton was found (Vigne et al. 2004). The most parsimonious although disputed (Rothwell 
2004) explanation of this find on a formerly cat-free island is that the cat had been transported by Neolithic farmers to the island on a raft or ship as it would not have been able to swim there on its own. This situation is suggestive of the beginning of the taming process (Vigne et al. 2004). The second important find are six cat skeletons, including those from four kittens, found in a pit in an elite cemetery of Predynastic Egypt around 3,700 BCE (Van Neer et al. 2014). Based on the age of the animals, the authors believe that these cats had been held in captivity, at least for some time (Van Neer et al. 2014). As in the case of the cat in Cyprus, this situation testifies to a change in the status of the animal with respect to humans, i.e., a tightening of their relationship. Thus, these early finds hint to the Fertile Crescent and Egypt as the areas where the cat first may have changed its behavior so that a co-existence with humans became possible. Since genetic data of extant cats clearly show that all domestic cats descend from F. s. lybica, the wildcat from NA and SWA, archeological and genetic data are in agreement albeit without proposing a refined view of the sequence of events taking place during the domestication process.

\subsection{The cat in ancient Egyptian iconography}

The second and richest source of information about the important place that cats occupied in ancient societies is Egyptian iconography (Málek 1993-2006; Engels 2001): cats were depicted in Egypt as early as 2200 BCE, first on ivory knives and as outlines carved in walls. Later, during the Middle Kingdom, they were painted as bird hunters in marshes in company of Egyptian hunters ("cat in the marshes") (Fig. 2). The presence of other wild animals, such as the genet and the ichneumon (the Egyptian mongoose) suggest that these cats were wildcats (Von den Driesch 1992). Some of the cats that hunted together with humans might also have been trained jungle cats, F. chaus, (Morrison-Scott 1952), but these are slightly bigger, lack the typical striped fur pattern of wildcats and have tufted ears, discriminative features that would have been faithfully transcribed in Egyptian paintings. During the New Kingdom, in the second 
half of the $2^{\text {nd }}$ millennium $\mathrm{BCE}$, another theme became more and more recurrent, i.e., the cat sitting under the chair of a noble person, mostly a woman, translating the growing bonds between cats and humans, and in particular women. Indeed, cats were a symbol of fertility and motherhood (Fig. 3A). By 1450 BCE cats were common in paintings of domestic scenes. Cats also assumed great importance in Egyptian religion from about 2000 BCE onwards (Málek 1993-2006; Engels 2001). From about 1500 BCE it was believed that the sun god Ra could manifest himself in the form of a cat, the 'Great Tomcat'. Each night Ra would travel to the underworld, confront his enemy, the snake demon Apophis, kill the snake with a knife and thus ensure the return of the sun the following morning. Many ancient Egyptian paintings depict Ra in the form of a spotted cat slaying Apophis and thus defeating the forces of chaos. By $945 \mathrm{BCE}$ the cat had become associated with a female divinity, the goddess Bastet, and with the funeral rituals. Indeed, sacred cats kept in temple catteries were worshipped as living embodiments or epiphanies of the goddess (Málek 1993-2006; Engels 2001; Machon 2015; Warmenbol 2015). The popularity of this cult of Bastet continued for over 1500 years into the Roman era (to 330 CE). Many beautiful bronze sculptures of cats survive from this period (Fig. 3B). Cat mummification became more and more important during the $1^{\text {st }}$ millennium $\mathrm{BCE}$ and in particular during the Ptolemaic period and millions of mummified cats had survived until the $19^{\text {th }}$ c. CE when large amounts of them were shipped to England where they were ground up and used as fertilizer (Málek 1993-2006).

Thus, Egyptian iconography is the richest archive testifying to the domestication of the cat: without changing appearance, it entered the domestic context. The dichotomy of the situations in which the cats are depicted, on one hand as skilled hunters that killed dangerous snakes and scorpions, as well as intelligent rats and mobile birds, and on the other hand sitting quietly under the chairs of noble people and as guardians of the deceased, suggests that the cat 
was appreciated as both a most useful hunter and a companion animal. This dual role was maintained in Greek, Etruscan and Roman iconography (Engels 2001; Luce 2015).

From the carvings, frescos and statues in Ancient Egypt, it is not possible to distinguish a domestic from a wildcat except for the context in which it is placed. To a certain degree this holds still true since the shape and appearance of wild-colored domestic cats are not radically different from those of wildcats (Krüger et al. 2009; Müller 2011). Most of the differences that can be noticed today are of very recent origin, such as the fancy breeds that were created from random-bred cat populations in a frenzy of innovation and experimental cross-breeding during the $19^{\text {th }}$ century in the Western World (Kurushima et al. 2013). The analysis of genomes of modern wild and domestic cats indeed showed a few differences, most of which are attributable to the genes involved in the development of the neural crest suggesting mainly behavioral changes (Montague et al. 2014). The resemblance of size and shape between the domestic cat and the wild ancestor is also seen in the skeletal remains of cats: wild and domestic cat bones and teeth cannot be distinguished on the basis of their metrics, unless one has complete skeletons or at least skulls (Wim van Neer, pers. comm.). It is only the archeological context that gives a hint about a change in the relationship between humans and cats, such as in the two examples described above.

Thus, from the three lines of evidence, i.e., mitochondrial DNA sequences and nuclear microsatellite DNA data from extant cats, the archeological record as well as Egyptian iconography, it was only possible to conclude that the cat must have been domesticated in SWA and/or NA from the subspecies F. s. lybica starting in the Early Neolithic, when huntergatherers became sedentary farmers. It was clear that in order to better characterize the domestication process of cats in time and space, DNA preserved in archeological cat remains had to be analyzed. Thus, we aimed at establishing the phylogeographic structure of the wildcat in North Africa, southwest Asia and Europe and to follow its evolution across time. 


\section{Paleogenetic analysis of cat remains}

Our team collected 352 ancient and 28 modern cat samples from all around the Mediterranean Basin and from Africa dated from $9,000 \mathrm{BP}$ to the beginning of the $20^{\text {th }}$ century (see supplementary tables of (Ottoni et al. 2017)). An example for such archeological remains is shown in Fig. 4. Knowing that we had to analyze archeological specimens from Egypt, the Levant and Syria, i.e., areas with a very hot climate where DNA is poorly preserved based on our previous experience analyzing other species, we developed a metabarcoding approach tailored to highly degraded, small DNA molecules that combines the sensitivity of PCR and the power of NGS for the analysis of many ancient samples at reasonable costs (Guimaraes et al. 2016). The approach uses highly optimized multiplex PCR to increase sample throughput without losing sensitivity and specificity of the PCR and proved to be powerful in various experimental systems (Cote et al. 2016; Guimaraes et al. 2016; Librado et al. 2017). The experimental design was such that through the analysis of the ND5, ND6 and CYTB region of the mitochondrial DNA (Ottoni et al. 2017), we achieved a phylogenetic resolution that was comparable to the one that had been obtained previously in extant cats (Driscoll et al. 2007). DNA was extracted and purified in the high containment laboratories of the University of Leuven and the Jacques Monod Institute using high stringency and DNA contamination prevention procedures (Champlot et al. 2010; Ottoni et al. 2017). Multiplex-PCR set-ups were performed in the high containment laboratory of the Jacques Monod Institute in Paris dedicated to ancient DNA research, while the construction of DNA libraries from the PCR products as well as Ion Torrent sequencing were carried out there in various modern DNA laboratories (Guimaraes et al. 2016; Ottoni et al. 2017).

It was the aim of our study to establish the phylogeographic structure of the wildcat populations in Europe, the Middle East and North Africa and to see whether we can detect changes that would disclose the domestication process. To achieve this aim, we analyzed many 
samples from these regions in order to compensate for samples that would not yield results and to increase the chance of detecting the emergence of a change in the geographical and temporal distribution pattern of mitotypes. This rationale of our experimental design turned out to be justified since DNA in most samples from Egypt, the Levant and Syria was so poorly preserved that they did not yield results. Moreover, it was the sheer number of samples that allowed us to draw conclusions on the domestication history of the cat.

\section{Knowledge gained from our paleogenetic analysis}

\subsection{Phylogeography of the wildcat}

Our oldest samples originated from western Europe dating to the Mesolithic period prior to the arrival of the Neolithic farmers that colonized Europe coming from Anatolia (e.g., (Lazaridis et al. 2016)) and introduced agriculture and domestic animals (e.g., (Özdogan 2011)). These cats as well as more recent ones belonged to the mitotype of the European wildcat $F . s$. silvestris (Fig. 5A). In southeast Europe, however, we detected in samples dating to $7700 \mathrm{BCE}$, i.e., before the arrival of the Neolithic farmers, a mitochondrial lineage of $F$. s. lybica, IV-A1, that differed from the one we found in Early Neolithic Anatolia named IV-A* (Fig. 5A). The split date of lineages IV-A1 and IV-A* has been estimated to roughly 20,000 years ago, i.e., the last glacial maximum (LGM), based on the calibration of the maximum likelihood tree obtained from about one third of the mitogenome (Fig. 6). At this time, the Bosphorus was still a land bridge and it is conceivable that the aridity of the climate in southeast Europe during the LGM would have allowed F. s. lybica, which is adapted to open bushland and deserts, to colonize the Balkans. At the end of the Pleistocene and beginning of the Holocene, forests would have extended again into the area and with it the forest-dwelling $F$. s. silvestris. A mosaic of open bushland and forest environments would have allowed the two different ecotypes, $F . s$. silvestris and F. s. lybica, to co-exist in this region. And indeed, we found both mitotypes in 
later periods and they still co-exist there to date although in two independent subspecies (Wozencraft 2005).

In Anatolia, not a single specimen analyzed carried the mitotype of $F$. s. silvestris. This finding was unexpected since Anatolia was so far considered to be inhabited by the European wildcat (Yamaguchi et al. 2015). Although we cannot exclude that these latter ones lived in the northern forests of Anatolia lining the Black Sea and had simply not been sampled, our data rather suggest that Anatolia was inhabited by F. s. lybica, at least up to the $13^{\text {th }}$ c. CE (Fig. 5A and B).

\subsection{The cat during the Neolithic}

Cat remains from the early Neolithic site of Asikli Höyük on the Konya plain in Anatolia that carry mitotype IV-A* testify to both the mitotype of the native Anatolian wildcat population, at least on the Anatolian highlands, and to cats in a human settlement suggestive of some change in the human-cat relationship (Fig. 5B). This view is reinforced through cat figurines found in Neolithic sites in Turkey, Syria and Israel (Vigne et al. 2004). In particular, the cat-like animals depicted on ceramic figurines of women from the Anatolian site Haçilar dated to ca. 8,000 BP could well be the first iconographic evidence of tamed cats, as proposed already in 1965 (Brentjes 1965), but later questioned (e.g., (Gautier 1999). The Anatolian mitotype IV-A* appeared in those of our samples from southeast Europe that were dated to the time when the Neolithic farmers migrated into Europe (e.g., (Lazaridis et al. 2016)), but not in earlier European specimens (Fig. 5C). Once again, the most parsimonious interpretation of this finding is that the cats had been translocated to Europe by the early farmers when they crossed the Bosphorus by boat suggesting that the cats were tamed or at least familiar with the presence of people. We also found the Anatolian mitotype in more recent samples $\left(2^{\text {nd }}-1^{\text {st }}\right.$ millennium BCE) from the Caucasus, the Levant, Iran, and Egypt (Fig. 5C). Since cats are territorial animals, the most parsimonious conclusion is that these cats have spread following humans on 
their migrations, in contrast to those types carrying lineage IV-B that were and remained endemic to the Levant. Taken together our genetic, but also archeological and ethological data, it comes naturally to mind that the first steps of the domestication of cats must have happened in the Fertile Crescent. Indeed, it was there where hunter-gatherers established the first permanent settlements, cultivated, collected and stored large amounts of wild grain as early as 13,000 years ago (Snir et al. 2015), and developed agriculture more than 10,000 years ago (e.g., (Bar-Yosef 1998; Belfer-Cohen and Bar-Yosef 2000; Asouti and Fuller 2012)). As a consequence, cereals in the field as well as grain accumulations must have attracted rodents that for their parts attracted the local wildcats. Wildcats that overcame their fear of humans and tolerated the presence of other cats would have found much better living conditions in or close to the settlements of the early farmers than in the wild, a situation still encountered nowadays in NA and Arabia (Faure and Kitchener 2009). In this way, the cat would have become a commensal, just as the rodents it preyed on, and its tameness would have been the result of a higher reward rate in human company compared to the wild. The human-cat relationship must have satisfied both sides from the very beginning of its establishment. Humans must have benefitted from cats that lived in and around the settlements since cats were the "bulwark" against rodent pests that depleted and spoiled the grain in the fields and in the stores causing starvation, famines and economic loss. Moreover, the spread of dangerous diseases carried by rodents, and in particular rats, would have been reduced. Egyptian cats were described as very big (Boessneck and von den Driesch 1983) compared to the cats in SWA (Davis 1987; Benecke 1994), as if they had been selected for as ratters (Faure and Kitchener 2009), while present-day domestic cats are poor killers of rats selecting only juveniles (Childs 1986). The find of six rat skeletons in the skeleton of an Egyptian cat (Boessneck and von den Driesch 1983), supports this hypothesis. 
Cats would also have fought venomous animals such as scorpions and snakes. Since the latter predate on rodents they must have come closer to human settlements where they became pests themselves. The depiction of cats as snake killers in Egyptian iconography might therefore be linked directly to the role of cats as adjuncts in early agriculture. The gradual nature of the move from the use of wild stands of cereal to cultivation of domesticated plants that took place at the transition from the hunter-gatherer to the agricultural life style could well constitute the context for an equally gradual development of the human-cat association.

\subsection{The Egyptian cat}

The cat mummies from the Ptolemaic period in Egypt that we analyzed carried two different mitochondrial lineages, the Anatolian lineage IV-A* and two lineages, IV-C1 and IV-C*, that we had not found in more ancient cats from other areas (Fig. 5D). These latter lineages were present also in Anatolian cats from the Roman-Byzantine period, where about half of the samples carried these IV-C lineages, a fourth carried the native lineage IV-A* and the rest lineages IV-E and F. s. ornata (Fig. 5E). We found them also in samples from the Levant and Iran dated to the Roman period and later even in a Viking port at the Baltic Sea (Fig. 5E).

This fast and massive spread of the "Egyptian cat" over large distances hints to sea vessels as dissemination means. Indeed, cats must have accompanied seafarers, from the Phoenicians (called "cat thieves by the ancient Egyptians (Faure and Kitchener 2009)) over Greeks, Etruscans to Romans, on their ships keeping the vessels rodent-free and taking advantage of fish as a food source that naturally is not readily available for cats. Rodents on ships are a threat not only to the food reserves but also to all organic material such as ropes that are being gnawed on. The usefulness of ship's cats can be deduced from the fact that until 1975 cats were compulsory on all the vessels of the British Navy (Beadle 1977) and some of them have been immortalized in novels, poems and got statues erected to celebrate their memory. That this was a widespread custom at the latest during Roman times can be deduced from a cat sample from 
the Egyptian-Roman port of Berenike at the Red Sea that carried the mitotype of the Asian wildcat, F. s. ornata. This port is known for its lively trading connections with India and the sailors spent several months on either end of their voyage giving their ship's cats the opportunity to mix with the local Asian wildcat the offspring of which would sometimes make the voyage back to the area where their ancestors came from. Alternatively, or in addition, Asian wildcats boarded the sea vessels and were shipped to Egypt and to the Eastern Mediterranean such as Anatolia, where we also found this mitotype in a few samples from coastal sites. Thus, our ancient mitochondrial data suggest that the spread of the "domestic" cat over the Ancient World occurred through seafaring merchants and soldiers, although the Roman army must have played an important role for the spread of the cat within the European continent as evidenced from archeological finds (e.g. (Bökönyi 1974, 1984; Clutton-Brock 1999)). During the $8^{\text {th }}$ and $9^{\text {th }} \mathrm{c}$. CE, the Vikings, traders as well as raiders, continued the dispersal of cats as evidenced by our finding of the Egyptian mitotype in the Baltic sea port of Ralswieck from the $8^{\text {th }} \mathrm{c} . \mathrm{CE}$, and so did the returning crusaders during the $11^{\text {th }}$ and $12^{\text {th }} \mathrm{c}$. CE (Lepetz 1996; Sunquist and Sunquist 2002).

\subsection{Selection of coat patterns in the domestic cat}

Ancient DNA analyses have shown for some animals such as horses that domestication led to an increase in the variety of coat colors as an early signature of the domestication process (Ludwig et al. 2009). In order to analyse whether this was also the case in cats and thereby obtain some information about the physical changes that the domestic cat potentially underwent through the domestication process, we analysed the Transmembrane Aminopeptidase $A$ (Taqpep) gene coding for the tabby coat pattern, the striped coat pattern of wildcats. A nonsense mutation (W841X) in exon 17 of the Taqpep gene causes the blotched pattern present in a large percentage of domestic cats (Kaelin et al. 2012) (Fig. 6). Indeed, the coat marking variations are used to discriminate wildcats and hybrids (e.g., (Beaumont et al. 2002; Pierpaoli et al. 2003; 
Oliviera et al. 2008)) while other coat color variations are described mainly in domestic cat breeds (for review see (Lyons 2015)).

We investigated in all of our samples three single nucleotide polymorphisms (SNPs) in this recessive allele and found it not earlier than just before the $13^{\text {th }} \mathrm{c}$. in SWA. It then increased in frequency in domestic cats in Europe, SWA and Africa suggesting that it was selected for. If we take this marker of appearance as a witness of the timing of selection for physical traits, this would represent a very late selection process in cats compared to other animals. This is not in contradiction to the genomic, archeological and iconographic evidence but only underlines the hypothesis that the cat has not been actively selected through breeding. Indeed, $85 \%$ of the 40 - 50 extant cat breeds arose only in the past 75 years (Kurushima et al. 2013). We would like to hypothesize that it was not necessary to "change" the cat since it was the perfect animal for human societies living in farms, villages and towns. From the very beginning it naturally performed the tasks that it was expected to do, i.e., hunting vermin and venomous animals, without being dangerous or trying to escape.

\section{Conclusions and Future Perspectives}

To conclude, we showed that two different clades of cats colonized subsequently the Ancient World, an Anatolian and an Egyptian one, confirming that both locations played an important role in the domestication history of cats. The dates and areas where these clades appeared in our extensive data set speaks for translocations as the mechanism of spread: first the somehow tamed cat followed humans on their migrations into new territories (Fig. 5G) and later it was transported as ship's cats with seafarers on routes of trading and warfare confirming a previous hypothesis (Kirk 1977). 
Since the underlying cause of cat domestication, grain accumulations in human settlements attracting rodents and thereby attracting cats preying on them, was generalized when the Neolithic began to spread, it is likely that the domestication process had several foci. Once cats interacted more closely with humans, they were translocated over much larger distances than they would have roamed on their own. Thus, any new genetic change affecting cats in one of the areas that would have been interesting to humans could then have been rapidly propagated to other locations. We believe that this is what happened with the Egyptian cats. To detect this process, as we did in our data set, we need to assume that, apart from Egypt, the bonds between cats and humans were probably still loose at the time of Classical Antiquity, and these cats were not abundant enough to dilute the genetic contribution of the newcomers. Later on, the process of spread of novel genetic variations must have continued, but becomes increasingly more difficult to detect with the cat-human relationship growing closer everywhere. We think that one should consider the domestication process of cats as a gradual spread over several thousands of years rather than a limited number of key founding domestication events. The simplified view of a limited number of key founding events is prone to be challenged by new archeological finds.

Further insights from the study of whole genomes of ancient cats at archeological key sites are expected to refine our knowledge of the domestication process of the cat. Indeed, additional information could be obtained if it was possible to sequence the genomes of cat remains predating the period when cats started to be translocated in order to establish baseline genomes, to which genomes from later stages of the cat domestication process can be compared. Such baselines are important since it is clear that hybridization between wild and tamed cats associated with the human niche was recurrent with the consequence of blurring the picture of the process that modified the genome of the house cats. The methodologies for this enterprise exist, but the task is not easy since DNA is poorly preserved in most skeletal remains from the 
presumed centers of cat domestication due to the high temperature in these regions that is detrimental to DNA preservation. Moreover, it is likely that many samples need to be analyzed to detect gradual changes in the frequency of a limited number of relevant alleles. Nevertheless, this analysis is necessary if one wants to confirm the hypothesis deduced from the diachronic analysis of the tabby coat color allele (Ottoni et al. 2017) that selection of physical traits has been a late event in the domestication process, which in turn suggests that the domestication process of the cat followed the commensal pathway (Zeder 2012) and was relaxed and long.

Acknowledgments: We would like to thank an anonymous reviewer for his/her interesting propositions. 


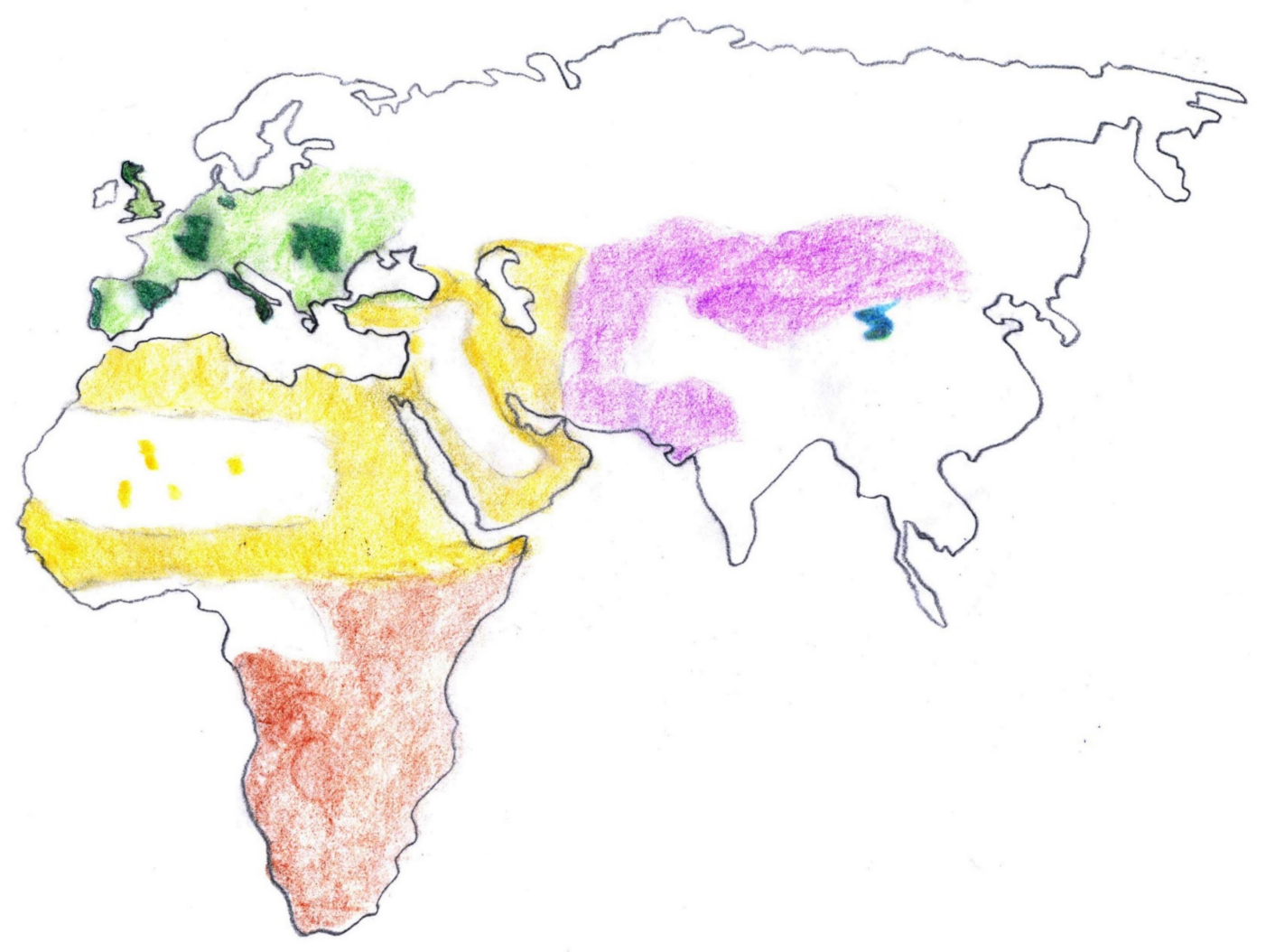

Fig. 1: Distribution of wildcats based on IUCN (Yamaguchi et al. 2015) and data from (Ottoni et al. 2017). Drawing: E.-M. Geigl. ๑ Springer International Publishing AG, part of Springer Nature 2018.

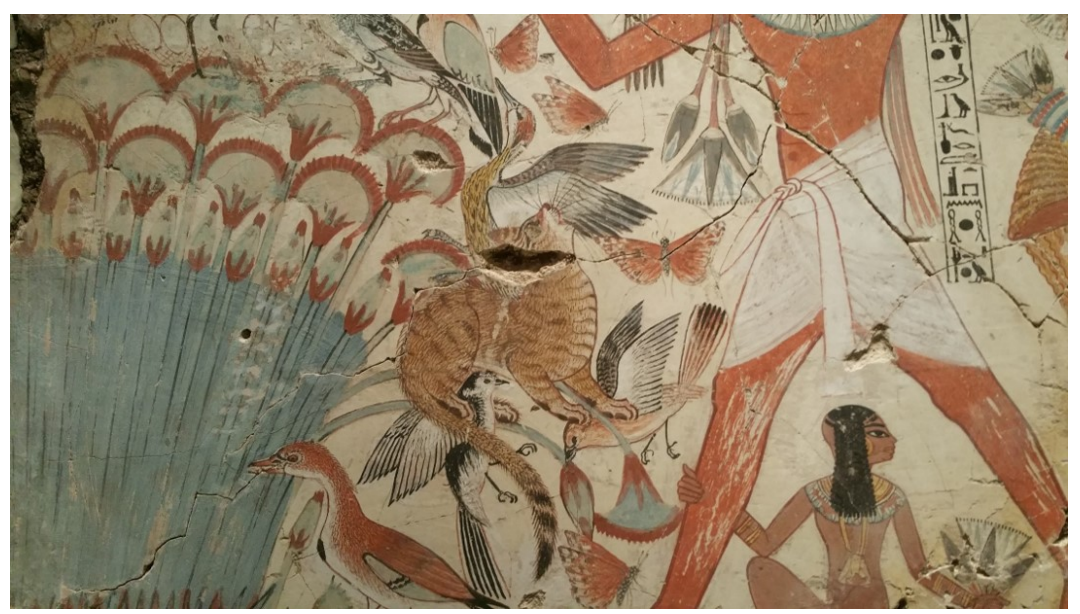

Fig. 2: Detail of cat from the hunting scene (fowling scene) from the tomb of Nebamun, Thebes, Egypt, 18th dynasty, ca. 1400-1350 BCE (British Museum, London, UK). Photo ๑ Thierry Grange . ㅇ Springer International Publishing AG, part of Springer Nature 2018. 


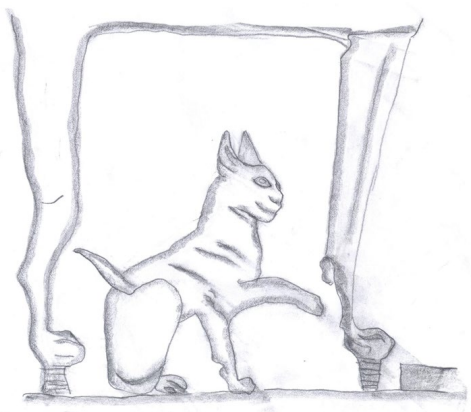

A

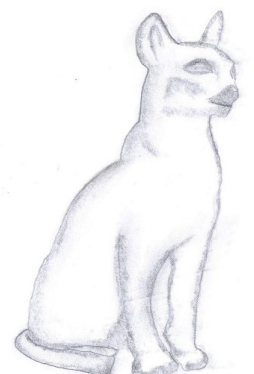

B

Fig. 3: A. Bas relief of a "cat under the chair" from the tomb of Mery-mery, $1391-1353$ BCE, Sakkara, Dynasty 18 (Rijksmuseum van Oudheden, Leiden, Netherlands). B. Statue of Bastet (Naturmuseum Senckenberg, Frankfurt, Germany). Drawing: E.-M. Geigl. ๑ Springer International Publishing AG, part of Springer Nature 2018.

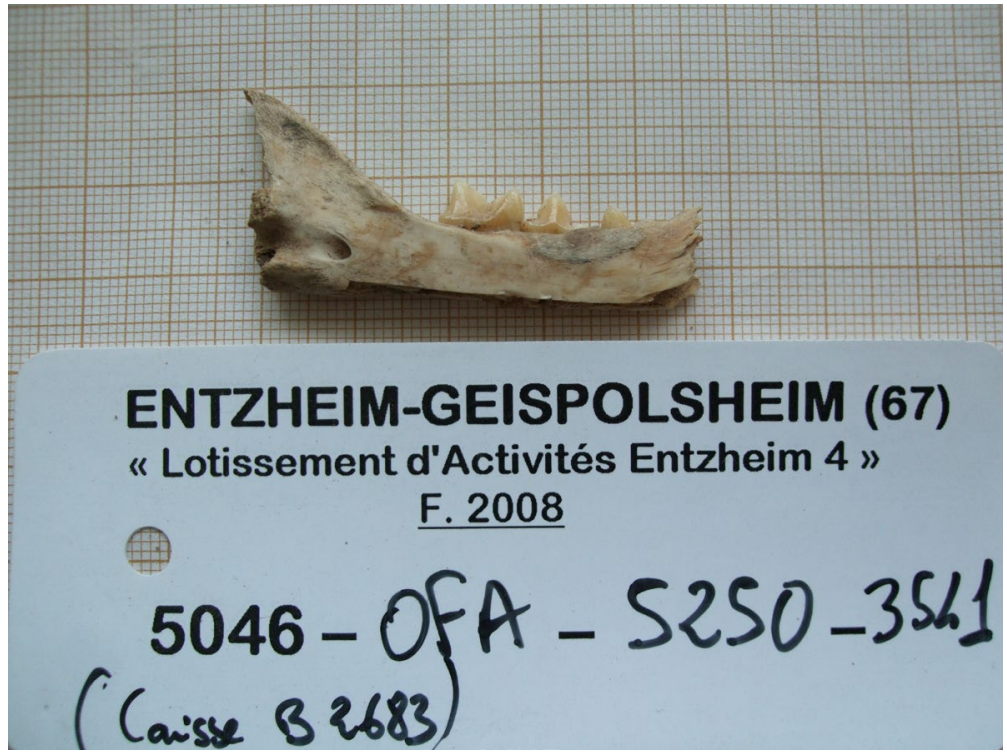

Fig. 4: cat mandible from the archeological site of Entzheim-Geispolsheim, France, dated to around 2,400 years ago (archeozoological determination: Olivier Putelat). ๑ Springer International Publishing AG, part of Springer Nature 2018. 

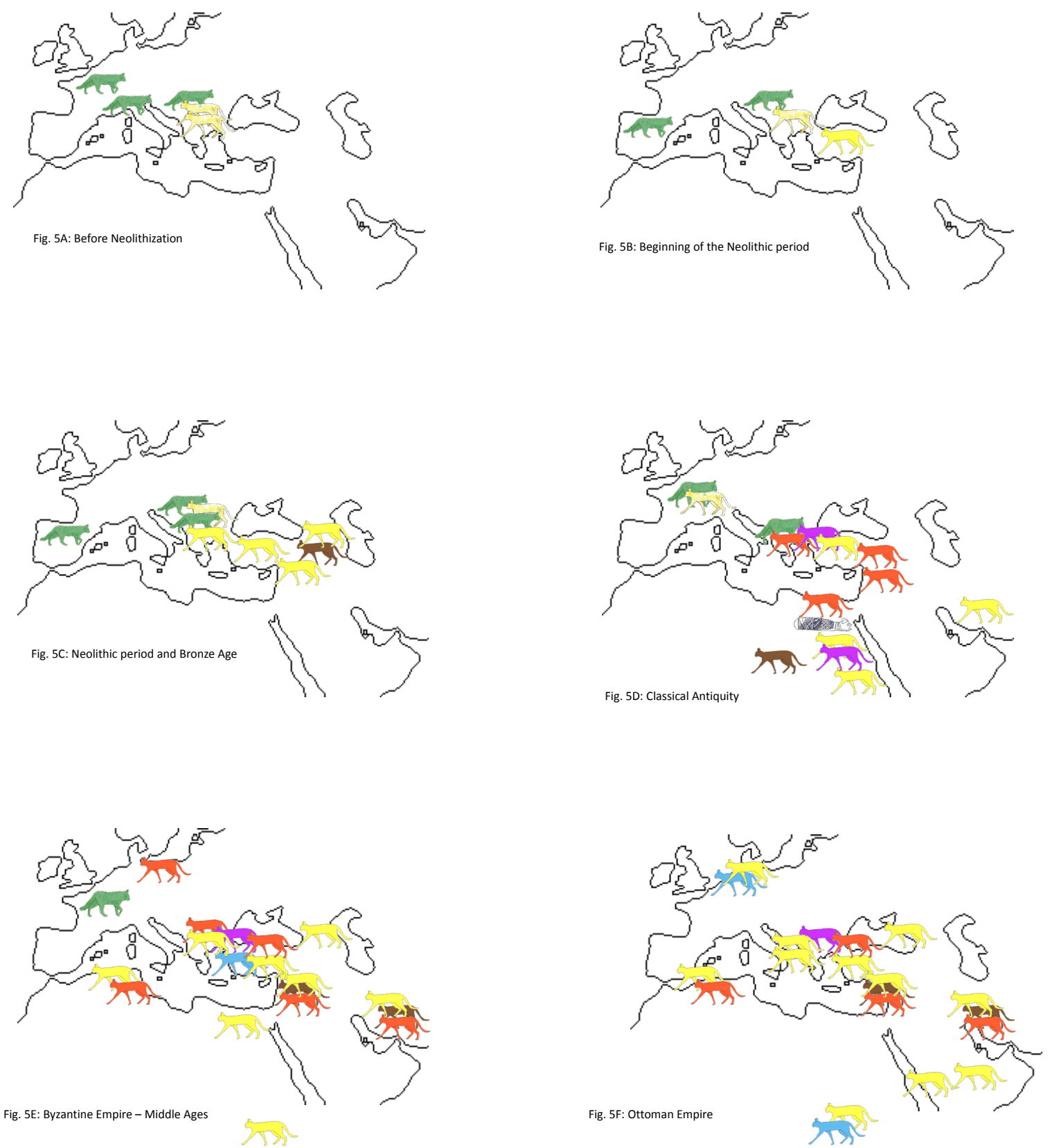
Fig. 5: Occurrence of the various mitotypes (F. s. silvestris = green; F. s. lybica mitotype IV-A1 = fade yellow; F. s. lybica mitotype IV-A* = yellow; F. s. lybica mitotype IV-C1 and $\mathrm{C}^{*}=$ orange; $F$. s. lybica mitotype IV-B = brown; F. s. lybica mitotype IV-E = light blue; F. s. ornate mitotype $=$ purple) in our data over time. A. Before Neolithization. B. At the beginning of the Neolithic period. C. Neolithic period and Bronze Age. D. Classical Antiquity. E. Byzantine Empire and Middle Ages. F. Ottoman Empire. G. Migration routes of cats deduced from the distribution through time and space of the different mitotypes. $\odot$ Springer International Publishing AG, part of Springer Nature 2018.

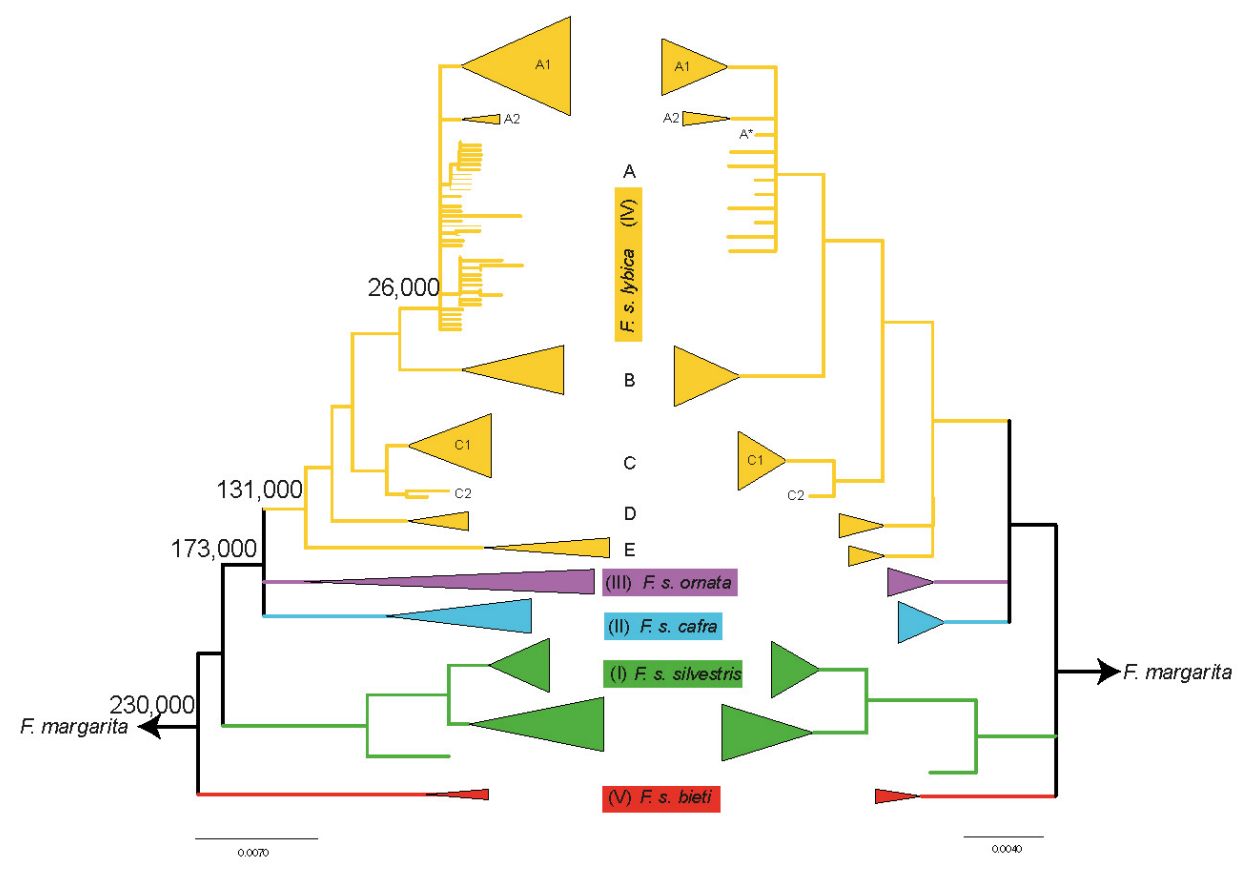

Fig. 6: Maximum-likelihood trees based on haplotype sequence data generated by Driscoll et al. (2007) (left) and of the same haplotype data reduced to the minimum sequence length -286 bp - generated by our assay (Ottoni et al. 2017) (right). Subspecies and clade names as described by Driscoll et al. (2007) are reported in the rectangular shape between the trees. Names of subclades within clade IV (F. s. lybica), as defined by Ottoni et al. (2017), are 
reported in each tree. Some of the subclades and lineages observed in the 2007 study of Driscoll et al. were collapsed in a single haplotype $\left(\mathrm{A}^{*}\right)$. Dates of the nodes were as estimated by Driscoll et al. (2007) except for the date of the node at the root of the IV-A haplogroup that we estimated using the Driscoll et al. dates. ๑ Springer International Publishing AG, part of Springer Nature 2018.

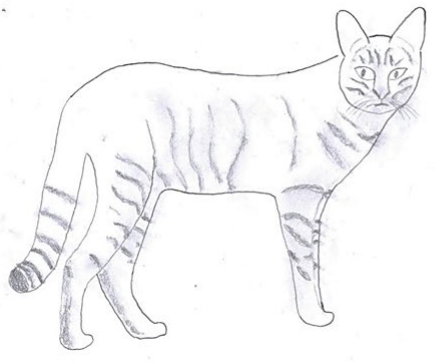

F. s. lybica - Tabby mackerel

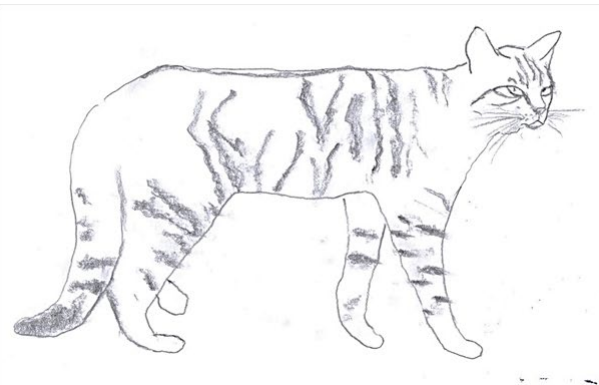

F. s. silvestris - Tabby mackerel
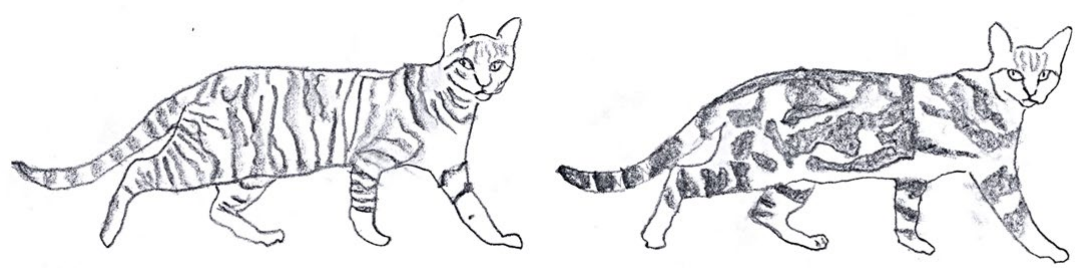

Domestic cats - Tabby mackerel - Tabby blotched

Fig. 7: Tabby mackerel coat pattern in wildcats (F. s. lybica, left, F. s. silvestris, right) and domestic cats; tabby blotched coat pattern in domestic cats. Drawing: E.-M. Geigl. ๑ Springer International Publishing AG, part of Springer Nature 2018. 
References:

Asouti E, Fuller DQ (2012) From foraging to farming in the southern Levant: the development of Epipaleolithic and Pre-pottery Neolithic plant management stragies. Vegetation History and Archaeobotany 21:149-162

Bar-Yosef O (1998) The Natufian culture in the Levant, threshold to the origins of agriculture. Evolutionary Anthropology 6/5:159-177

Beadle M (1977) The Cat: History, Biology, Behavior. Simon and Schuster, New York

Beaumont M, Barratt EM, Gottelli D, Kitchener AC, Daniels MJ, Pritchard JK (2002) Genetic diversity and introgression in the Scottish wildcat. Molecular ecology 10:319-336

Belfer-Cohen A, Bar-Yosef O (2000) Early sedentism in the Near East: A bmpy ride to village life. In: Kuijt I (ed) Life in Neolithic farming communities: social organization, identity, and differentiation. Kluwer/Plenum Press, New York, pp 19-37

Benecke N (1994) Der Mensch und seine Haustiere - Die Geschichte einer jahrtausendealten Beziehung. Theiss Verlag, Stuttgart

Boessneck J, von den Driesch A (1983) Ein Katzenskelett der Römerzeit aus Quscir (Koser) am Roten Meer. Spixiana 6:285-289

Bökönyi S (1974) History of Domestic Animals. Mammals in Central and Eastern Europe. Publicationes Instituti Archaeologici Academiae Scientiarum Hungaricae, Studia Archaeologica. Akadémiai Kiado, Budapest

Bökönyi S (1984) Animal Husbandry and Hunting in Tac-Gorsium: The Vertrebrate Fauna of a Roman Town in Pannonia. Publicationes Instituti Archaeologici Academiae Scientiarum Hungaricae, Studia archaeologica. Akadémiai Kiado, Budapest

Brentjes B (1965) Die Haustierwerdung im Orient. In: Ziemsen A (ed) Der Neue Brehm. Wittenberg Verlag,

Champlot S, Berthelot C, Pruvost M, Bennett EA, Grange T, Geigl EM (2010) An efficient multistrategy DNA decontamination procedure of PCR reagents for hypersensitive PCR applications. PloS one 5 (9):e13042. doi:10.1371/journal.pone.0013042

Childs JE (1986) Size-dependent predation on rats (Rattus norvegicus) by house cats (Felis catus) in an urban setting. Journal of Mammology 67:196-199

Clutton-Brock J (1999) A Natural History of Domesticated Animals. Cambridge University Press, London and Cambridge

Cote NM, Daligault J, Pruvost M, Bennett EA, Gorge O, Guimaraes S, Capelli N, Le Bailly M, Geigl EM, Grange T (2016) A New High-Throughput Approach to Genotype Ancient Human Gastrointestinal Parasites. PloS one 11 (1):e0146230. doi:10.1371/journal.pone.0146230

Davis SJM (1987) The Archaeology of Animals. B.T. Batsford Ltd., London

Driscoll CA, Menotti-Raymond M, Roca AL, Hupe K, Johnson WE, Geffen E, Harley EH, Delibes M, Pontier D, Kitchener AC, Yamaguchi N, O'Brien SJ, Macdonald DW (2007) The Near Eastern Origin of Cat Domestication. Science 317 (5837):519-523. doi:10.1126/science.1139518

Engels DW (2001) Classical Cats: The Rise and Fall of the Sacred Cat. Routledge, Abingdon

Ewing E (1981) Fur in dress. Batsford, London

Faure E, Kitchener AC (2009) An Archaeological and Historical Review of the Relationships between Felids and People. Anthrozoos 22 (3):221-238. doi:10.2752/175303709X457577

Gautier A (1999) Fauna, domesticated. Encyclopedia of the Archaeology of Ancient Egypt. Routledge, London, New York

Guimaraes S, Pruvost M, Daligault J, Stoetzel E, Bennett EA, Cote NM, Nicolas V, Lalis A, Denys C, Geigl EM, Grange T (2016) A cost-effective high-throughput metabarcoding approach powerful enough to genotype $\sim 44000$ year-old rodent remains from Northern Africa. Molecular ecology resources 17 (3):405-417. doi:10.1111/1755-0998.12565

Kaelin CB, Xu X, Hong LZ, David VA, McGowan KA, Schmidt-Kuntzel A, Roelke ME, Pino J, Pontius J, Cooper GM, Manuel H, Swanson WF, Marker L, Harper CK, van Dyk A, Yue B, Mullikin JC, 
Warren WC, Eizirik E, Kos L, O'Brien SJ, Barsh GS, Menotti-Raymond M (2012) Specifying and sustaining pigmentation patterns in domestic and wild cats. Science 337 (6101):1536-1541. doi:10.1126/science.1220893

Kirk M (1977) The everlasting Cat. Galahad Books, New York

Krüger M, Hertwig ST, Jetschke G, Fischer MS (2009) Evaluation of anatomical characters and the question of hybridization with domestic cats in the wildcat population of Thuringia, Germany. J Zool Syst Evol Res 47:268-282. doi:10.1111/j.1439-0469.

Kurushima JD, Lipinski MJ, Gandolfi B, Froenicke L, Grahn JC, Grahn RA, Lyons LA (2013) Variation of cats under domestication: genetic assignment of domestic cats to breeds and worldwide random bred populations. Animal Genetics 44 (3):311-324. doi:10.1111/age.12008

Lazaridis I, Nadel D, Rollefson G, Merrett DC, Rohland N, Mallick S, Fernandes D, Novak M, Gamarra B, Sirak K, Connell S, Stewardson K, Harney E, Fu Q, Gonzalez-Fortes G, Jones ER, Roodenberg SA, Lengyel G, Bocquentin F, Gasparian B, Monge JM, Gregg M, Eshed V, Mizrahi AS, Meiklejohn C, Gerritsen F, Bejenaru L, Bluher M, Campbell A, Cavalleri G, Comas D, Froguel P, Gilbert E, Kerr SM, Kovacs $P$, Krause J, McGettigan D, Merrigan M, Merriwether DA, O'Reilly S, Richards MB, Semino O, Shamoon-Pour M, Stefanescu G, Stumvoll M, Tonjes A, Torroni A, Wilson JF, Yengo L, Hovhannisyan NA, Patterson N, Pinhasi R, Reich D (2016) Genomic insights into the origin of farming in the ancient Near East. Nature 536 (7617):419-424. doi:10.1038/nature19310

Lepetz S (1996) L'animal dans la société gallo-romaine de la France du Nord. Revue Archéologique de Picardie (Amiens):S12

Librado P, Gamba C, Gaunitz C, Der Sarkissian C, Pruvost M, Albrechtsen A, Fages A, Khan N, Schubert M, Jagannathan V, Serres-Armero A, Kuderna LFK, Povolotskaya IS, Seguin-Orlando A, Lepetz S, Neuditschko M, Theves C, Alquraishi S, Alfarhan AH, Al-Rasheid K, Rieder S, Samashev Z, Francfort HP, Benecke N, Hofreiter M, Ludwig A, Keyser C, Marques-Bonet T, Ludes B, Crubezy E, Leeb T, Willerslev E, Orlando L (2017) Ancient genomic changes associated with domestication of the horse. Science 356 (6336):442-445. doi:10.1126/science.aam5298

Luce J-M (2015) Les chats dans I'Antiquité grecque. In: Bellier C, Cattelain L, Cattelain P (eds) Chiens et chats dans la Préhistoire et l'Antiquité. Editions de Cedarc,

Ludwig A, Pruvost M, Reissmann M, Benecke N, Brockmann GA, Castanos P, Cieslak M, Lippold S, Llorente L, Malaspinas AS, Slatkin M, Hofreiter M (2009) Coat color variation at the beginning of horse domestication. Science 324 (5926):485. doi:10.1126/science.1172750

Lyons LA (2015) DNA mutations of the cat. Journal of Feline Medicine and Surgery 17:203-219

Machon C (2015) Le culte du chat en Egypte ancienne. In: Chiens et chats dans la Préhistoire et I'Antiquité. Bellier, C., Cattelain, L., Cattelain, P. (eds), Editions de Cedarc.

Málek J (1993-2006) The cat in ancient Egypt, revised edition. The British Museum Press, London

Mattucci F, Oliveira R, Lyons LA, Alves PC, Randi E (2015) European wildcat populations are subdivided into five main biogeographic groups: consequences of Pleistocene climate changes or recent anthropogenic fragmentation? Ecol Evol 6 (1):3-22. doi:10.1002/ece3.1815

Montague MJ, Li G, Gandolfi B, Khan R, Aken BL, Searle SMJ, Minx P, Hillier LW, Koboldt DC, Davis BW, Driscoll CA, Barr CS, Blackistone K, Quilez J, Lorente-Galdos B, Marques-Bonet T, Alkan C, Thomas GWC, Hahn MW, Menotti-Raymond M, O'Brien SJ, Wilson RK, Lyons LA, Murphy WJ, Warren WC (2014) Comparative analysis of the domestic cat genome reveals genetic signatures underlying feline biology and domestication. Proc Natl Acad Sci USA 111 (48):1723017235. doi:10.1073/pnas.1410083111

Morrison-Scott TCS (1952) The mummified cats of ancient Egypt. Proceedings of the Zoological Society of London 121:861-867

Müller $F$ (2011) Körpermerkmale als Unterscheidungskriterien zwischen wildfarbenen Hauskatzen (Felis s. catus) und Wildkatzen (Felis silvestris silvestris, Felidae) aus Mitteleuropa. Beiträge zur Jagd- und Wildforschung 36:359-368 
Oliviera R, Godinho R, Randi E, Alves PC (2008) Hybridization vs conservation: are domestic cats threatening the genetic integrity of European wildcat (Felis silvestris silvestris) populations in Iberian peninsula? Philosophical Transaction fo the Royal Society B 363:2953-2961

Ottoni C, Van Neer W, De Cupere B, Daligault J, Guimaraes S, Peters J, Spassov N, Prendergast ME, Boivin NL, Morales-Muñiz A, Balasescu A, Benecke N, Boroneanț A, Buitenhuis $\mathrm{H}$, Chahoud J, Crowther A, Llorente L, Manaseryan N, Monchot H, Onar V, Osypińska M, Putelat O, Quintana Morales EM, Studer J, Wierer U, Decorte R, Grange T, Geigl EM (2017) The palaeogenetics of cat dispersal in the ancient world. Nature Ecology and Evolution 1 (0139). doi:10.1038/s41559017-0139

Özdogan M (2011) Archaeological evidence on the westward expansion of farming communities from eastern Anatolia to the Aegean and the Balkans. Current Anthropology 52:S415-S430

Pierpaoli M, Biro ZS, Herrmann M, Hupe K, Fernandes M, Ragni B, Szemethy L, Randi E (2003) Genetic distinction of wildcat (Felis silvestris) populations in Europe, and hybridization with domestic cats in Hungary. Molecular ecology 12 (10):2585-2598

Rothwell T (2004) Evidence for taming of cats - Response to J.-D. Vigne and J. Guilaine. Science 305:1714

Snir A, Nadel D, Groman-Yaroslavski I, Melamed Y, Sternberg M, Bar-Yosef O, Weiss E (2015) The Origin of Cultivation and Proto-Weeds, Long Before Neolithic Farming. PloS one 10 (7):e0131422. doi:10.1371/journal.pone.0131422

Sunquist MN, Sunquist F (2002) Wild Cats of the World. University of Chicago Press, Chicago

Van Neer W, Linseele V, Friedman R, De Cupere B (2014) More evidence for cat taming at the Predynastic elite cemetery of Hierakonpolis (Upper Egypt). J Arch Sci 45 (0):103-111. doi:http://dx.doi.org/10.1016/j.jas.2014.02.014

Vigne J-D, Guilaine J, Debue K, Haye L, Gérard P (2004) Early taming of the cat in Cyprus. Science 304 (5668):259. doi:10.1126/science.1095335

Von den Driesch A (1992) Kulturgeschichte der Hauskatze. In: Schmidt V, Horzinek MC (eds) Krankheiten der Katze, vol 1. Gustav Fischer Verlag, Jena, pp 17-40

Warmenbol E (2015) Le chien et le chat en Egypte pharaonique: à la vie, à la mort. Chiens et chats dans la Préhistoire et l'Antiquité. Editions du Cedarc,

Wozencraft C (2005) Felis silvestris. In: Wilson DE, Reeder DM (eds) Mammal Species of the World (3rd edition). Johns Hopkins University Press, Baltimore, p 2142

Yamaguchi N, Kitchener AC, Driscoll C, Nussberger B (2015) Felis silvestris. The IUCN Red List of threatened species 2015.

Zeder MA (2012) Pathways to Animal Domestication. In: Gepts P, Famula TR, Bettinger RL et al. (eds) Biodiversity in Agriculture. Cambridge University Press, Cambridge, pp 227-259 